\title{
POTENTIAL OF YEAST HYDROLYSATE ENZYMATIC FROM BAKER'S YEAST FERMENTED IN SEVERAL RICE FLOURS MEDIUM AS ANTI-DIABETES TYPE 2
}

\author{
R.Agustini ${ }^{1, *}$, I.G.M Sanjaya ${ }^{1}$, A. Sabarudin ${ }^{2}$ and A. Widodo ${ }^{3}$ \\ ${ }^{1}$ Department of Chemistry, Surabaya State University, Surabaya-60231, Indonesia \\ ${ }^{2}$ Department of Chemistry, Brawijaya University, Malang-65145, Indonesia \\ ${ }^{3}$ Department of Mathematic, Brawijaya University, Malang-65145, Indonesia \\ *E-mail: rudianaagustini@unesa.ac.id
}

\begin{abstract}
The number of people with type 2 DM continues to increase. This study aims to study the potential of Yeast Hydrolysate Enzymatic (YHE) as anti-type 2 DM. Yeast as a raw material for YHE is known to contain chromium which plays a role in reducing blood glucose levels. The white, red and black rice flour is used as yeast growth. This study also tested the potential of rice flour and yeast as a comparison. YHE in this study was used as an experimental animal feed for mice. YHE is determined the chemical content include: water, chromium (III) and (VI), protein, amino acids, starch, and crude fiber content. The parameters measured were glucose levels and mice body weight. Blood glucose levels of experimental animals affected by type 2 DM before and after YHE consumption for all treatments decreased. To find out the potential of YHE as anti-type 2, histology of liver and kidney tissue was also observed, as well as studies by chemical computation. The best treatment for YHE as anti-type 2 DM in this study, which was investigated from the reduction in glucose levels and body weight, was YHE-red rice (YHE-RR) feed. YHE's potential as an anti-type 2 DM was proved by histology of liver and kidney tissue. YHE's potential as an antitype $2 \mathrm{DM}$ is also proved by histology of liver and kidney tissue whereas the role of chromium in reducing glucose is supported by the results of the chemical computation. The result of this study shows that YHE from baker's yeast fermented in several rice flour medium can be used as anti-type 2 DM.

Keywords: Diabetes Mellitus Type 2, Fermentation, Yeast Hydrolysate Enzymatic, Chromium, Rice Flours
\end{abstract}

(C) RASĀYAN. All rights reserved

\section{INTRODUCTION}

Today many people suffer from a metabolic disorder known as type $2 \mathrm{DM}$, which is the inability of cells to absorb glucose which ultimately accumulates a lot of glucose in the blood. This is because the patient's body cannot use the insulin that is produced effectively, which is a hormone that regulates blood glucose levels. In the world, the number of sufferers of type 2 diabetes continues to increase, especially in developing countries. This will have an impact on adding to existing burdens, especially health services. Data from global studies show that the number of people with DM in 2011 has reached 366 million, and by 2030 it is estimated that the number of sufferers will increase to 552 million. Type 2 diabetes is influenced by lifestyle, eating patterns, as well as being overweight or obese. ${ }^{1}$

Some studies reveal that type $2 \mathrm{DM}$ can be reduced by consuming chromium, one of the trace minerals needed by the human body. Chromium is an important mineral that the body needs to metabolize carbohydrates and fats. ${ }^{2,3}$ Chromium can be obtained from foodstuff and is available in very small quantities (1-2 micrograms or less). Chromium in food is in the form of chromium (III) and chromium (VI). Chromium (III) is an important mineral that is known to have pharmacological effects and values, while chromium (VI) is toxic and carcinogenic. ${ }^{4}$ Trivalent chromium or chromium (III) is the most stable and safest form ${ }^{5}$, including one of the least toxic. ${ }^{6}$ Foodstuff, which is known to be rich in chromium, is a yeast since the Civil War era has been used to help balance blood sugar.

Rasayan J. Chem., 12(4), 2348-2357(2019)

http://dx.doi.org/10.31788/RJC.2019.1245411

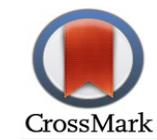


RASĀYAN J. Chem.

Yeast is better known as Saccharomyces cerevisiae. Schwarz and Mertz reported the results of their research that mice fed yeast-based feeds affect glucose tolerance, and identified that chromium (III) as an integral part of a protein known as glucose tolerance factor (GTF). ${ }^{7}$ Yeast can be grown in various media that are rich in carbohydrates and have been used as nutritional supplements for many years. Yeast is known to be rich in chromium and is beneficial in treating type 2 diabetes in several ways, including by increasing tolerance of glucose. The medical report of 1853 and supported by modern research shows that consumption of yeast at a dose of 9 grams/day is beneficial in treating type $2 \mathrm{DM}^{8,9}$ The supplement of chromium can increase tolerance of glucose in people with type $2 \mathrm{DM}^{10}$ Daily chromium intake according to the US diet guidelines is 50-200 mg for adults, 30-35 mg (adult men) and 20-25 mg (adult women). About $2 \%$ of chromium (III) or trivalent can be absorbed and the rest is excreted in feces. Amino acids, vitamin $\mathrm{C}$ and niacin can increase the absorption of chromium by the intestinal tract. This mineral then accumulates in the liver, bone, and spleen.

Chromium works to help the entry of glucose in the body's cells by increasing insulin resistance. If the amount of insulin in a person's body is insufficient or if the body's cells do not respond to insulin, there will be an accumulation of glucose in the blood (hyperglycemia) and a person will suffer from DM. This chromium can be obtained from food consumed daily. Chromium can form complexes with picolinate (chromium picolinate), with niacin (chromium niacin), with glycin (chromium glycin), with Dphenylalanin (chromium D-phenylalanin), and chromium salicylate. ${ }^{11}$ The regulation of blood glucose levels by chromium is known that chromium interacts with low molecular weight chromium molecules (the low-molecular-weight chromium/LMWCr). ${ }^{12}$ This LMWCr (molecular weight $\sim 1500$ Dalton) oligopeptide was composed of amino acids, glycine, cysteine, glutamate, and aspartate. ${ }^{13}$ The interaction of chromium with LMWCr will activate the binding of insulin with receptors on cells. On the other hand, there are compounds in the cell that play a role in the negative regulation of insulin signal transduction at the receptor, namely protein tyrosine phosphatase (PTP 1B). Negative regulatory mechanisms by PTP IB molecules that have an impact on the uptake of glucose from the blood by cells have been studied.

Yeast which is known to contain chromium can be grown in a laboratory. To get the maximum yeast it is necessary to optimize the influential conditions, including growth media. The media used must match the requirements, in this case, it contains simple carbohydrates. Yeast can metabolize various carbohydrates, but mainly uses sugars such as glucose, sucrose, and maltose. ${ }^{14}$ Complex carbohydrates can be utilized, but these compounds must be hydrolyzed in advance to produce simple carbohydrates so that yeast can be used directly for growth. Carbohydrate-rich foods including rice. There are several kinds of rice, namely white, red, and black rice. This foodstuff is known to have different chemical compositions and glycaemic indices. Complex carbohydrates in rice flour must be degraded into simple molecules so that they can be used directly by the yeast. The degradation process can be carried out enzymatically using $\alpha$-amylase and the results will be more perfect if $\alpha$-amylase is combined with glucoamylase. The yeast that is successfully grown in various media then hydrolyzed enzymatically and this will produce a product known as YHE. ${ }^{15}$ The quality of a product must be tested for its potential, which in its early stages tested its potential in experimental animals, namely mice. The potential test for anti-DM can be seen by measuring the decrease in glucose levels before treatment and after treatment. Chromium is a group of trace minerals needed in small amounts but must be sufficient. Consumption in large or excessive quantities can damage other organs such as other minerals, including the liver and kidneys. Daily chromium intake according to US diet guidelines is $50-200 \mathrm{mg}$ for adults ${ }^{16}$. The processing can result in a decrease or maybe an increase in the chromium content in the sample, therefore it needs to be tested for the chromium content after the treatment process and it's potential as anti DM Type 2. The base background this study to describe the potential of YHE from yeast fermented in rice flour medium as anti type $2 \mathrm{DM}$. The results of the research that has been done are expected to be able to contribute to handling DM type 2 problems that are suffered by many people and can utilize Indonesian natural resources so that they can bring in foreign exchange.

\section{EXPERIMENTAL}

The research carried out was an experimental laboratory with the three following stages: (1) YHE preparation as mice feed, (2) conditioning of mice to indicate type $2 \mathrm{DM}$ and (3) giving YHE diet to mice 
RASĀYAN J. Chem.

Vol. 12 | No. 4 | 2348 - 2357| October - December | 2019

followed by measurement of blood glucose, body weight and mice activity before and after YHE consumption.

\section{Preparation of YHE}

Three kinds of Rice flours were used as a yeast growth medium in this study such as red, white, black rice flours. White rice (WR), red rice (RR) and black rice (BR) were ground, then sifted through 100 mesh. The next step is adding distilled water to each rice flour in the ratio of $5: 1(\mathrm{w} / \mathrm{v})$. The mixture was heated to boiling, and finally, a gel (gelatinization process) would be formed. The gel was allowed to cool then hydrolyzed using $\alpha$-amylase and glucoamylase enzymes for 6 hours at room temperature $\left(28 \pm 5^{\circ} \mathrm{C}\right)$. Starch would be broken down by both enzymes so that the gel thickness decreases. The hydrolysate was ready to be used as a yeast growth medium. The yeast used was a commercially available baker's yeast. Yeast was put into hydrolysate with a ratio of $5: 1(\mathrm{v} / \mathrm{w})$, then fermented for 10 days to obtain a slurry. The fermentation results are centrifuged at $6000 \mathrm{rpm}$ for 15 minutes. The residue was hydrolyzed using bromelain as proteases. Hydrolysis in this study was carried out at $37^{\circ} \mathrm{C}$ for 24 hours. The hydrolyzate obtained was YHE. YHE is tested for its chemical content including water, chromium (III), chromium (VI), protein, crude fiber, $\alpha$-amino acids, and starch content. Water content was tested using the gravimetry method, chromium (III) and (VI) levels using the cyclic voltammetry method ${ }^{17}$, the protein content was determined by the Kjeldahl method ${ }^{18}$. Determination of amino acids using HPLC (Waten, model 244), with a 420-AC fluorescence detector model. The starch level was determined by the colorimetry method with iodine reagent, and crude fiber using the AOAC method. ${ }^{18}$

\section{Adaptation Stage of Mice}

The mice used were male mice aged \pm 4 weeks, body weight \pm 30 grams obtained from Gadjah Mada University, Indonesia. For the initial stage of adaptation, mice were placed in the cage according to the treatment to be given. Mice were adapted for 7 days and fed during adaptation with commercial feed and given drinking which was replaced every day. The next step was to observe the behavior of mice. Mice were weighed one by one using a digital balance and then measured their blood glucose levels using a multi check device of Nesco.

\section{Induction of Obesity to Increase Blood Glucose Levels in Mice}

Obesity induction was done by giving fat and fructose feed. Animal fat was given every day at $0.4 \mathrm{~mL}$, fructose was given at $0.6 \mathrm{~mL}$ and commercial feed every day for approximately 1 week. The next step was to observe mouse activity, measure blood glucose levels and body weight.

\section{The Treatment of Mice with the YHE diet}

Mice that have been exposed to DM were fed according to the treatment of YHE and White rice flour (YHE-WR), YHE red rice (YHE-RR) and YHE black rice (YHE-BR).In this study it was also carried out as a comparison, namely feeding white rice flour (WR), red rice (RR), black rice (BR), white rice yeast (yeast-WR), red rice yeast (Yeast-RR), and black rice yeast (yeast-BR), and also as a positive control that was treated by giving glibenclamide, negative control, and normal control. The overall treatment of mice was shown in Table-1.

\begin{tabular}{c|c}
\hline \multicolumn{2}{|c}{ Table-1: Treatment of Mice } \\
\hline Rice Flours Treatment & $\begin{array}{c}\text { Diabetic and non-diabetic mice were treated with flour- } \\
\text { WR, flour-RR, and flour-BR. }\end{array}$ \\
\hline Treatment of Yeast & $\begin{array}{c}\text { Diabetic and non-diabetic mice were treated with yeast- } \\
\text { WR, yeast-RR, and yeast-BR. }\end{array}$ \\
\hline Treatment of YHE & $\begin{array}{c}\text { Diabetic and non-diabetic mice were treated with YHE- } \\
\text { WR, YHE-RR, and YHE-BR. }\end{array}$ \\
\hline $\begin{array}{c}\text { Glibenclamideadministration } \\
\text { (Positive Control) }\end{array}$ & $\begin{array}{c}\text { As a positive control, mice were treated with } \\
\text { glibenclamide in } 1 \% \text { Na-CMC with the dose of } 0.013 \mathrm{mg} \\
/ 20 \text { grams of mouse weight to make them in diabetic } \\
\text { condition. }\end{array}$ \\
\hline $\begin{array}{c}\text { Diabetes Control (Negative } \\
\text { Control) }\end{array}$ & \begin{tabular}{c} 
Diabetic mice were treated by only giving 1\% Na-CMC. \\
\hline Normal Control
\end{tabular} \\
\hline Non-diabetic mice were treated with 1\% Na-CMC.
\end{tabular}


RASĀYAN J. Chem.

Vol. 12 | No. 4 |2348 - 2357| October - December | 2019

The next step was weighing, measuring blood glucose levels and the activity of mice that have been treated.

\section{RESULTS AND DISCUSSION}

Many factors cause DM, including diet. Food factors can affect the risk of type $2 \mathrm{DM} .{ }^{19}$ The prevalence of type 2 diabetes is $99 \%$ of all people with diabetes. ${ }^{20}$ Many research or efforts have been made in dealing with type 2 diabetes, which uses synthetic drugs and natural ingredients. The use of synthetic drug supplements including picolinate chromium, phenylalanine chromium, metformin, acarbose. Research on the natural compound as anti-DM has been carried out, including brewing yeast, ginseng, and garlic. This study uses a natural compound as anti-type 2 DM, namely YHE. YHE had been made from baker's yeast that fermented in rice flour media as anti DM type 2. The rice flour media used for yeast growth are white, red and black rice which have a different glycemic index. Yeast has been known to contain chromium which is thought to have the potential to increase insulin resistance, a hormone that plays a role in regulating blood glucose. In this study to determine the potential of YHE as an anti-DM type 2 include: level reduction of blood glucose, liver and kidney histology, and simulation results using chemical computation.

\section{Chemical Analysis of Various Mice Feeds}

YHE in this study used the experimental animal feed in this study were mice. The research was carried out using rice flour gelatinized to produce porridge and yeast as a comparison. YHE's potential as an antitype $2 \mathrm{DM}$ result is strongly influenced by the chemical composition of feed or intake every day. The chemical analysis results of all mice feed in this work was given in Table-2.

Table-2: Chemical Composition of Mice Feeds

\begin{tabular}{c|c|c|c|c|c|c|c}
\hline Feed Type & $\begin{array}{c}\text { Water } \\
\text { Content } \\
(\%)\end{array}$ & $\begin{array}{c}\text { Cr(III) } \\
(\%)\end{array}$ & $\begin{array}{c}\text { Cr(V } \\
\text { I) } \\
(\%)\end{array}$ & $\begin{array}{c}\text { Protein } \\
(\%)\end{array}$ & $\begin{array}{c}\alpha \text {-amino } \\
\text { nitrogen(N- } \alpha) \text { total } \\
(\%)\end{array}$ & $\begin{array}{c}\text { Crude } \\
\text { Fiber } \\
(\%)\end{array}$ & $\begin{array}{c}\text { Starch } \\
(\%)\end{array}$ \\
\hline Flour-WR & 89.00 & $20 \times 10^{-4}$ & $48 \times 10^{-4}$ & 7.45 & $\mathrm{nM}$ & 3.09 & 33.95 \\
\hline Flour-RR & 89.00 & $19 \times 10^{-4}$ & $49 \times 10^{-4}$ & 9.06 & $\mathrm{n} . \mathrm{m}$ & 2.43 & 17.96 \\
\hline Flour-BR & 89.00 & $20 \times 10^{-4}$ & $53 \times 10^{-4}$ & 10.60 & $\mathrm{n} . \mathrm{m}$ & 1.31 & 13.26 \\
\hline Yeast-WR & 77.00 & $101 \times 10^{-4}$ & $48 \times 10^{-4}$ & 40.00 & $\mathrm{n} . \mathrm{m}$ & 6.77 & 9.47 \\
\hline Yeast-RR & 74.06 & $103 \times 10^{-4}$ & $49 \times 10^{-4}$ & 38.00 & $\mathrm{n} . \mathrm{m}$ & 5.89 & 6.64 \\
\hline Yeast-BR & 72.21 & $113 \times 10^{-4}$ & $53 \times 10^{-4}$ & 40.19 & $\mathrm{n} . \mathrm{m}$ & 6.00 & 5.42 \\
\hline YHE-WR & 52.95 & $32 \times 10^{-4}$ & $15 \times 10^{-4}$ & 38.45 & 7.58 & 14.88 & 8.03 \\
\hline YHE-RR & 58.29 & $37 \times 10^{-4}$ & $17 \times 10^{-4}$ & 38.48 & 6.93 & 13.15 & 5.15 \\
\hline YHE-BR & 62.67 & $40 \times 10^{-4}$ & $19 \times 10^{-4}$ & 39.23 & 8.09 & 11.71 & 2.61 \\
\hline
\end{tabular}

n.m : not measured

As shown in Table-2, the highest Cr(III) content was found in yeast-BR feed of $113 \times 10^{-4} \%$. Similarly, YHE-BR contains the highest $\mathrm{Cr}$ (III) content among YHE-type feeds. The different in $\mathrm{Cr}(\mathrm{III})$ contents between yeast- and flour- types of WR, WW, and BR were $81 \%, 84 \%$, and $93 \%$. The fermentation of yeast-type feeds resulted in the formation of YHE-type feeds. This fermentation process successfully decreased the toxic Cr (VI) levels. As shown in Table-2, $\mathrm{Cr}$ (VI levels in yeast-WR, yeastRR, and yeast-BR declined about $33 \%, 32 \%$, and $44 \%$, respectively. The highest protein content was found in the yeast-BR feed, and after fermentation, it contributed to the highest amount of protein content in YHE-BR as compared with other YHE-type feeds. As also given in Table 2, the analysis of crude fiber showed that the highest content of this element could be attributed to YHE-WR. The lowest amylum concentration was found in YHE-BR which has the highest amount of amino acid $(\mathrm{N}-\alpha)$.

Effect of Feeds to Blood Glucose Levels (BGL) and Body Weight Loss (BWL) of Mice

The initial stage of the YHE potential test as anti-type 2 DM is the adaptation stage. It observed that during this stage, the activity of mice appeared normal active and agile in motion. The second stage is the 
RASĀYAN J. Chem.

Vol. 12 | No. 4 | 2348 - 2357| October - December | 2019

induction of obesity using fructose, and fat in combination with the commercial feed. At this stage, mice appeared more active, and drink more frequently. Moreover, as time goes by, the movement of mice became slower and their bodies seemed thinner. The third stage is treatment with YHE-WR, YHE-RR, YHE-BR, flour-WR, flour-RR, flour-BR, yeast-WR, Yeast-RR, and yeast-BR; administration of glibenclamide, negative controls, and normal control. After these treatments, it was observed that mice appeared fresher along with a decrease in their glucose levels and normal body weight as shown in Table3 and Table-4.

Table-3: Blood Glucose Levels (BGL) of Mice Before And After Treatment With Various Feeds

\begin{tabular}{c|c|c|c|c}
\hline No & Feed Type & $\begin{array}{c}\text { BGL Before } \\
\text { Treatment } \\
(\mathrm{mg} / \mathrm{dL})\end{array}$ & $\begin{array}{c}\text { BGL After } \\
\text { Treatment } \\
(\mathrm{mg} / \mathrm{dL})\end{array}$ & $\begin{array}{c}\text { Decrease in } \\
\text { BGL (mg/dL) }\end{array}$ \\
\hline 1 & Flour -WR & 140 & 70 & 70 \\
\hline 2 & Flour -RR & 156 & 36 & 120 \\
\hline 3 & Flour-BR & 144 & 55 & 89 \\
\hline 4 & Yeast -WR & 142 & 44 & 161 \\
\hline 5 & Yeast-RR & 174 & 43 & 127 \\
\hline 6 & Yeast -BR & 183 & 54 & 92 \\
\hline 7 & YHE-WR & 140 & 52 & 76 \\
\hline 8 & YHE -RR & 178 & 48 & 60 \\
\hline 9 & YHE -BR & 152 & 53 & 69 \\
\hline 10 & $\begin{array}{c}\text { Diabetes }+ \\
\text { Glibenclamide } \\
\text { (positive control) }\end{array}$ & 140 & 64 & 69 \\
\hline 11 & $\begin{array}{c}\text { Commercial feed }+ \\
\text { CMC-Na (normal } \\
\text { control) }\end{array}$ & 132 & 73 & \\
\hline & $\begin{array}{c}\text { CMC-Na (negative } \\
\text { control) }\end{array}$ & 143 & 74 & \\
\hline
\end{tabular}

Table-3 showed that the decrease in BGL of mice treated with the flour-type feed from the highest to the lowest level was giving dietary flour-RR $>$ flour-BR $>$ glibenclamide (positive control) $>$ flour$\mathrm{WR}>$ negative control $>$ normal control. Similarly, in case of the yeast treatment, the highest to the lowest reduction of BGL was found on the following order of diet: yeast-BR>yeast-RR = YeastWR $>$ glibenclamide (positive control) $>$ negative control $>$ normal control, whereas BGL reduction from the highest to lowest after YHE feed treatment was YHE-RR $>$ YHE-BR $>$ YHE-WR $>$ glibenclamide (positive control) $>$ negative control $>$ normal control. Table-3 also showed that the decrease in BGL of mice treated with the YHE-RR diet was the highest of all the treatments given. Table-4 showed a decrease in the body weight of mice after giving a diet with variations in feed types.

Table-4: Body Weight Loss (BWL) of Mice After Giving A Diet With Various Type of Feeds

\begin{tabular}{c|c|c|c|c}
\hline No & Feed Type & $\begin{array}{c}\text { Body Weight Before } \\
\text { Treatment (gram) }\end{array}$ & $\begin{array}{c}\text { Body Weight } \\
\text { After Treatment } \\
\text { (gram) }\end{array}$ & $\begin{array}{c}\text { Weight } \\
\text { Loss } \\
\text { (gram) }\end{array}$ \\
\hline 1 & Flour-WR & 23 & 17 & 6 \\
\hline 2 & Flour-RR & 27 & 22 & 4.3 \\
\hline 3 & Flour-BR & 29 & 23 & 6 \\
\hline 4 & Yeast-WR & 27 & 22 & 4.3 \\
\hline 5 & Yeast-RR & 15 & 13 & 3.3 \\
\hline 6 & Yeast-BR & 25 & 15 & 9.7 \\
\hline 7 & YHE-WR & 28 & 21 & 7 \\
\hline 8 & YHE-RR & 26 & 20 & 5 \\
\hline 9 & YHE -BR & 29 & 21 & 7.3 \\
\hline 10 & Diabetes + & 29 & 25 & 4.3 \\
\hline
\end{tabular}


RASĀYAN J. Chem.

Vol. 12 | No. 4 | 2348 - 2357| October - December | 2019

\begin{tabular}{c|c|c|c|c}
\hline & (Positive Control) & & & \\
\hline 11 & $\begin{array}{c}\text { Commercial feed }+ \\
\text { CMC-Na (Normal } \\
\text { Control) }\end{array}$ & 30 & 24 & 6 \\
\hline 12 & $\begin{array}{c}\text { CMC-Na } \\
\text { (Negative Control) }\end{array}$ & 30 & 23 & 7 \\
\hline
\end{tabular}

According to Table-4, the lowest to the highest decrease of mice body weight in the treatment of rice flour feed was in the following order: flour-RR $<$ flour-BR $=$ Flour-WR. While the decrease in body weight of mice for yeast feed treatment from the lowest to the highest was yeast-RR <yeast-WR <yeastBR. Moreover, the treatment of YHE feeds decreased the weight of mice from the lowest to the highest as follows: YHE-RR <YHE-WR = YHE-BR, whereas, in the control treatment, the lowest to highest decrease in body weight of mice was glibenclamide (positive control)<normal control<negative control. Among all treatments, the lowest weight loss of mice was found in mice treated with yeast-BR.

Based on the data in Table-3 and Table-4 it can be seen that the best ability to reduce blood glucose (161 $\mathrm{mg} / \mathrm{dL}$ ) was mice treated with yeast-RR, while the treatment with this feed also resulted in the lowest weight loss (3.3 grams) during administration feed for 1 week. These results proved that yeast-RR could be attributed as the best anti-DM among all feeds treatment in this work.

Similarly, YHE-RR also has a good ability to reduce blood glucose levels. It is because YHE contains amino acids, carbohydrates, and micronutrients. As well known, amino acids are very important for mouse cell growth. The highest amino acid content in YHE products is glutamic acid. Such results also showed that the ability of glibenclamide, which is commonly used as an anti-diabetes drug in reducing blood glucose levels, is still smaller in comparison to YHE-RR, CMC-Na (normal control) and negative control.

\section{Liver and Renal Kidney Histology of Mice after Treated with Various Types of Mice Feed}

YHE potential test results as anti-DM were investigated from the ability of each feed in reducing blood glucose (BGL) and weight loss (BWL) rats supported by histological data of liver and kidney tissue. DM can affect vital organ systems including the liver and kidneys which lead to more severe and irreversible pathological conditions such as diabetes nephropathy ${ }^{21}$ and hepatopathy. Diabetic nephropathy is the ability of nephrons to filter down blood, while hepatopathy is damage to hepatocytes (liver cells). ${ }^{21}$ Fig.-1 and 2 show the renal and liver histology of mice indicated by type 2 DM and recovery with YHE.

Figure-1 showed the recovery of liver tissue damage of mice exposed to type 2 DM with various treatments of feeds. The successful recovery of damaged liver tissue was assessed through negative control (DM + CMC-Na) and normal control (CMC-Na) indicators. Treatment with yeast-RR and YHERR feeding showed small tissue damage in comparison to other treatments, and mainly to negative controls. This result indicated that the recovery rate of liver tissue damage by yeast-RR feed treatment and YHE-RR was good. The best treatment was achieved by giving yeast-RR feed. Figure- 2 showed the histology of kidney tissue with high blood glucose levels $>140 \mathrm{mg} / \mathrm{dL}$ in mice and the recovery of renal tissue damage in mice exposed to type $2 \mathrm{DM}$ with various treatments for feeding. The successful recovery of damaged kidney tissue was assessed through negative control (DM + CMC-Na) and normal control (CMC-Na) indicators. Treatment with yeast-RR feeding showed the best recovery results compared to other treatments.

Diabetes mellitus (DM) is strongly influenced by the diet consumed by someone. Food consumed by a person or other living things influences the microflora of the existing intestine. Intestinal microflora can affect insulin resistance and obesity so that it can cause type 2 diabetes. Intestinal microflora plays a role in the pathogenesis of type $2 \mathrm{DM}$, which is to increase or decrease body weight, bile metabolism in the liver, and resistance of insulin, and intestinal hormone modulation ${ }^{21}$ as also proved by the result of this work shown in Table-3 and Table-4 in which each of the feeds consumed showed varying blood glucose levels in mice.

The feed tested mainly contains different levels of chromium as presented in Table-1. Glucose entering the cell is assisted by the hormone of insulin which involves chromium ions. If the amount of insulin in 
RASĀYAN J. Chem.

Vol. 12 | No. 4 | 2348 - 2357| October - December | 2019

the body is insufficient or if the body's cells do not respond to insulin, then glucose will accumulate in the blood (hyperglycemia), and someone will be suffering from DM. This chromium can be obtained from food consumed daily. The role of chromium in regulating blood glucose levels is not widely understood, but it has recently been known that this process involves the interaction of chromium with low-weight molecules known as chromium interacting with low molecular weight chromium or LMWCr. ${ }^{12}$ Interactions between LMWCr and chromium will increase insulin activity. Therefore, the YHE potential as an anti-DM not only can be seen from the ability of each feed tested in reducing blood glucose levels (BGL) of mice but also can be indicated by the presence of different chromium content.
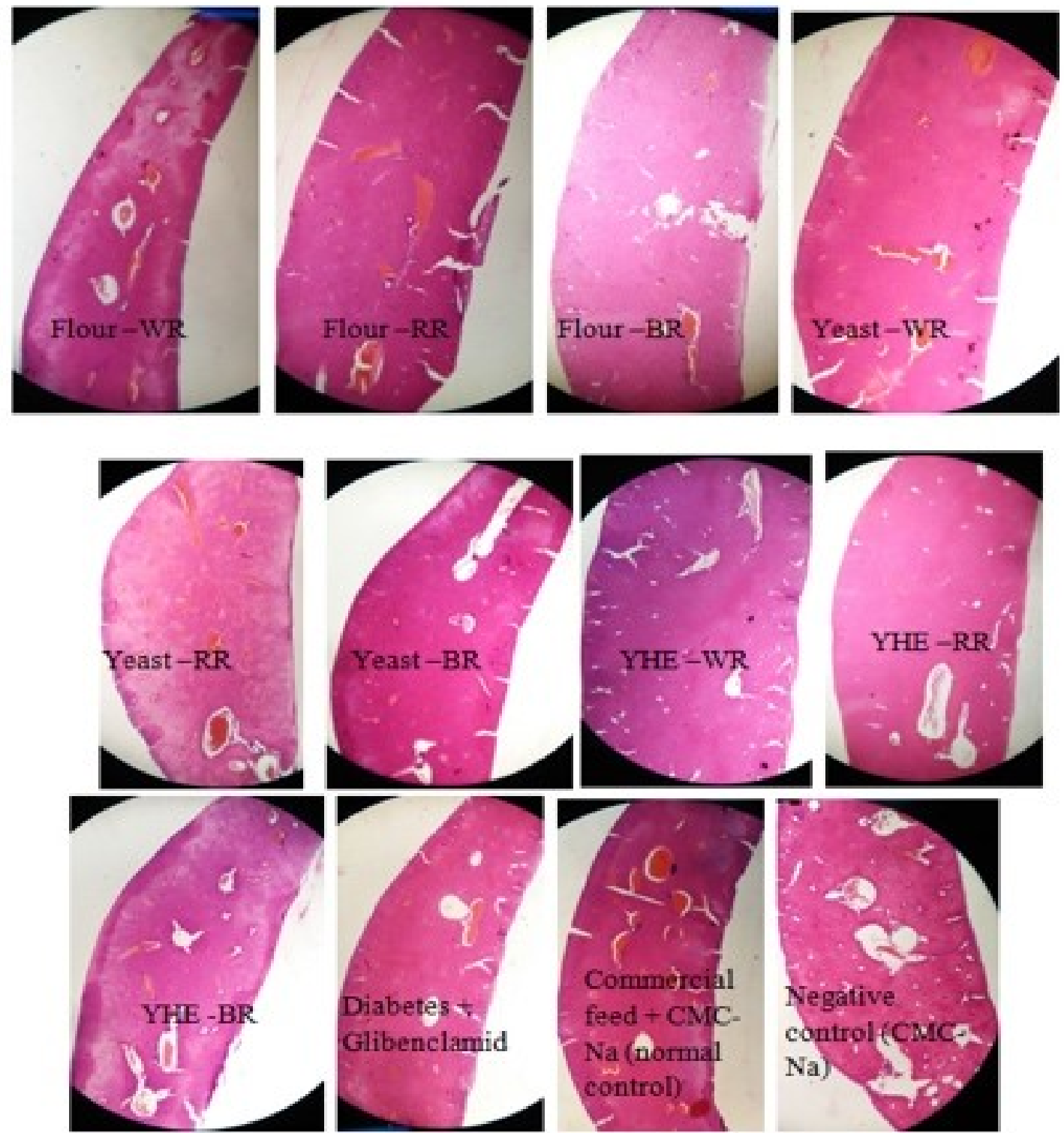

Fig.-1: Liver Histology of Mice in Various Feed Treatments with Hematoxylin-Eosin Staining

The role of chromium in lowering levels of blood glucose in mice is also supported by the results of computational chemistry using Autodock software whose results are chemically computed using NWChem 6.0. ${ }^{22}$ describing the interaction model of chromium represented by chromium picolinate with GLUT I. Glut I is a membrane protein to transport or not a specific type of charged substrate across the cell membrane through a diffusion process or an active transport process ${ }^{23}$, and it has the character as 
RASĀYAN J. Chem.

Vol. 12 | No. 4 | 2348 - 2357| October - December | 2019

shown in Table-5. The picolinate salt of chromium which is very important in glucose metabolism has molecular characteristics as shown in Table-6.

The interaction between GLUT 1 and Chromium (III) picolinate was studied by means of molecular docking as shown in Figure 3. The formation of complex compounds illustrated in Figure 3 has a total SCF energy of -2342.407 Hartree and surface area of $424527 \AA^{2}$.

Table-5: The Characteristic of GLUT 1 in Humans

\begin{tabular}{c|c}
\hline Properties & Value \\
\hline Molecular Formula & $\mathrm{C}_{2308} \mathrm{H}_{3627} \mathrm{~N}_{562} \mathrm{O}_{598} \mathrm{~S}_{22}$ \\
\hline Molecular Weight & $49489.5 \mathrm{~g} / \mathrm{mol}$ \\
\hline Number of Atoms & 7117 or 3490 (without $\mathrm{H}$ ) \\
\hline Area of Surface & $18750 \AA^{2}$ \\
\hline
\end{tabular}
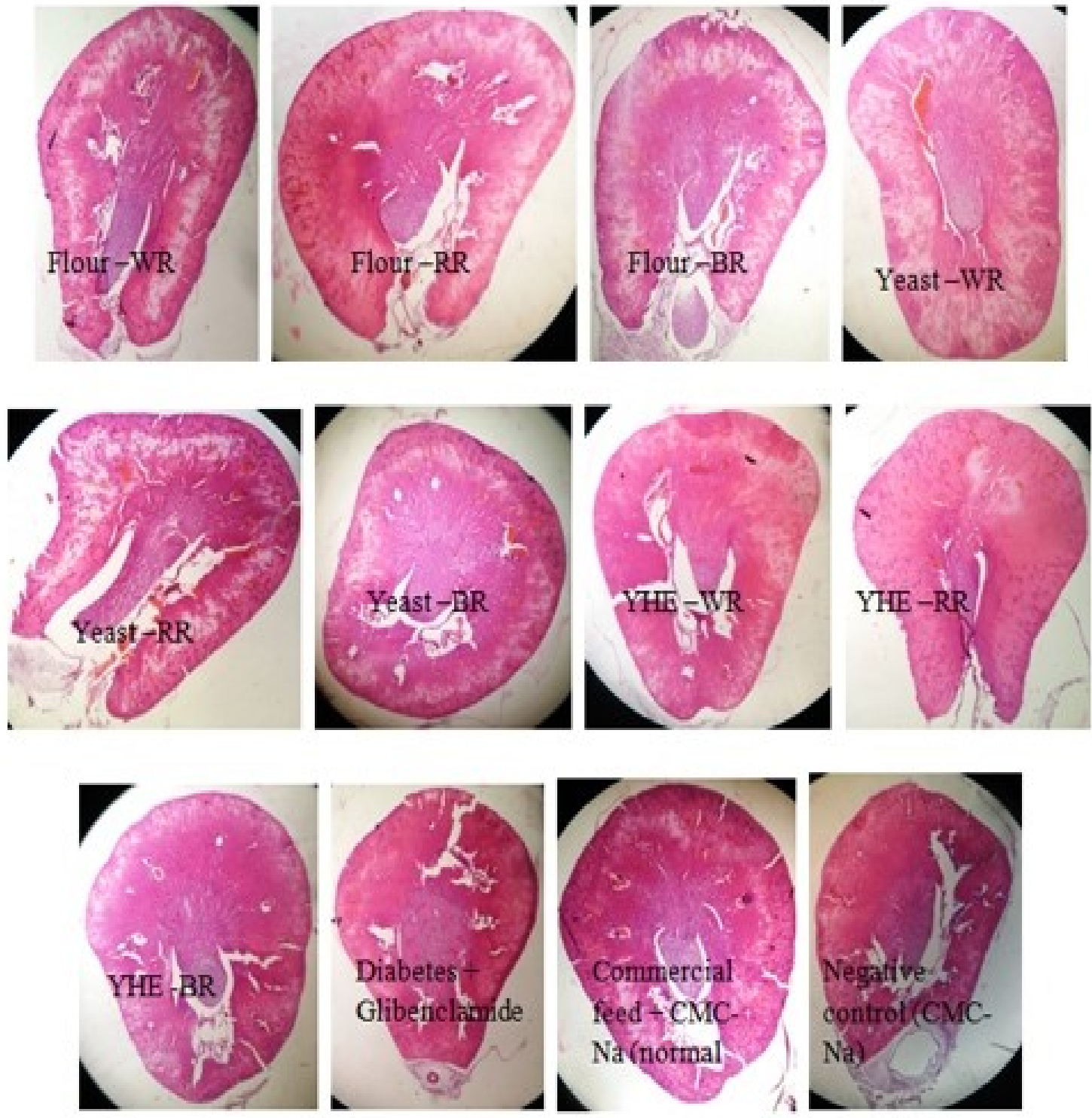

Fig.-2: Histology of Kidneys in Various Treatments of Feed with Hematoxylin-Eosin Staining.

Based on the aforementioned simulation, it can be stated that chromium (III) has a stable interaction with GLUT 1. This interaction resulted in an increase in the surface area of GLUT 1 ( $\left.\sigma_{\text {GLUT-1 }}\right)$ to 23 times 
RASĀYAN J. Chem.

Vol. 12 | No. 4 | 2348 - 2357| October - December | 2019

larger (from $18750 \AA^{2}$ to $424527 \AA^{2}$ ). The increase in surface area is predicted to increase GLUT 1 reactivity in transporting glucose into cells.
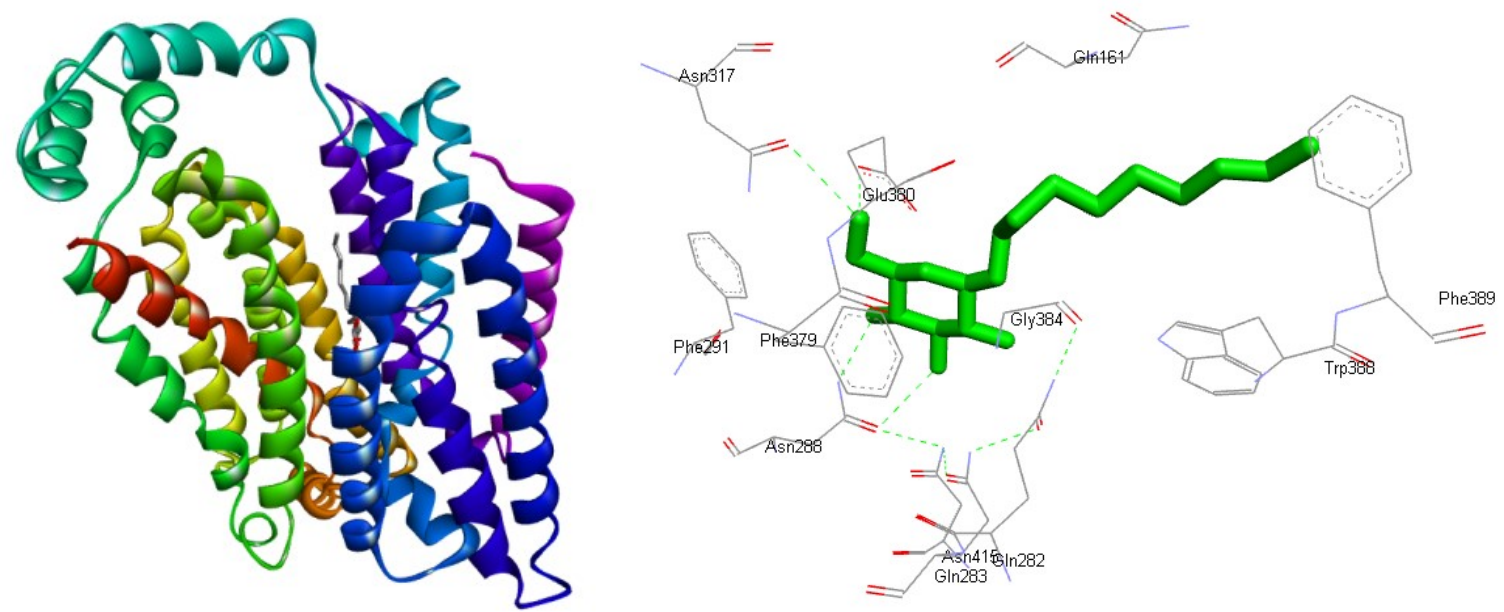

Fig.-3: Compound Of GLUT-1 Complex and Chromium (III) Picolinate (Left) with Ligand Interaction (Right)

Table-6: The characteristic of Chromium (III) picolinate

\begin{tabular}{c|c}
\hline Properties & Value \\
\hline Molecular formula & $\mathrm{C}_{18} \mathrm{H}_{12} \mathrm{CrN}_{3} \mathrm{O}_{6}$ \\
\hline Molecular Weight & $418305 \mathrm{~g} / \mathrm{mol}$ \\
\hline Number of atoms & 28 atom \\
\hline Area of surface & $159 \AA^{2}$ \\
\hline
\end{tabular}

\section{CONCLUSION}

Blood glucose levels (BGL) of experimental animals being suffered by Type II DM decreased after YHE consumption for all feed treatments. The best treatment for YHE as anti-TYPE 2 DM in this study, which was indicated by the reduction in glucose levels and body weight, was YHE-RR. YHE's potential as an anti-type $2 \mathrm{DM}$ is also proved by histology of liver and kidney tissue whereas the role of chromium in reducing glucose is supported by the results of the chemical computation.

\section{ACKNOWLEDGMENT}

The author would like to thank the Research Ministry, Technology and Higher Education of the Indonesia Republic and the Chancellor of Surabaya State University for providing research funding assistance.

\section{REFERENCES}

1. A.B. Olokob, O.A. Obateru, A. Olusegun and L.B. Olokoba, Oman Med. J., 27(4), 269(2012), DOI: $10.5001 /$ omj.2012.68

2. B.E. Wilson, A. Gondy, Effects of Chromium Supplementation on Fasting Insulin Levels and Lipid Parameters in Healthy, Non-obese Young Subjects, Diabetes Research and Clinical Practice (1995).

3. J. B. Vincent, Journal of Nutr. Therap. Interv. Diabetes. Metab. Syndr., 381(2012)

4. Wise, S. Sandra and J. P. Wise, Journal of Mutation Research,733(1),78(2012), DOI: 10.1016/j.mrfmmm.2011.12.002

5. H. Oliveira, Journal of Botany, (2012).

6. R.A. Anderson, N. Cheng, N.A. Bryden, M.M. Polansky, N. Cheng and J. Chi, J. Diabetes, 46, 1786(1997).

7. S. Lewicki, R. Zdanowski, M. Krzyżowska, A. Lewicka, B. Dębski, M. Niemcewicz and M. Goniewicz, Ann. Agric. Environ. Med., 21(2), 331(2014), DOI: 10.5604/1232-1966.1108599

8. Health Encyclopedia, Chromium, (2019).

9. E.G. Offenbacher and F.X. Pi-Sunyer, J. Diabetes., 29, 919(1980).

10. G.W. Evans, Int. J. Biosocial. Med. Res., 11, 163(1989). 
11. A.F.Z.M. Salem, Strategies of Animal Feed Additives. Nova Science Publishers, Inc. New York (2013).

12. Y. Chen, H.M. Watson, J. Gao, S.H. Sinha, C.J. Cassady and B. Vincent, J. Nutr., 141(7), 1225(2011).

13. Y. Hua, S. Clark, J. Ren and N. Sreejayan, J. NutrBiochem. 23(4), 313(2012), DOI: $10.1016 /$ j.jnutbio.2011.11.001

14. A. Bekatoro, C. Psarianos and A.A. Koutinas, Food Technol. Biotechnol., 44(3), 407(2006).

15. T. Godfrey, and J. Reichet, Industrial Enzymology, The Application of Enzyme in Industry, Great Britain: Stockton Press (1986).

16. P. Trumbo, A. Yates, S. Schicker and M. Poos, J. Am. Diet. Assoc., 101(3), 294(2001).

17. E. Yulianto, Unesa Journal of Chemistry, 3(3), 60 (2014).

18. AOAC, Official Methodes of Analysis Of Association Of Official Analytical Chemists. Washington D.C. (2000).

19. S. Tian, Q. Xu, R. Jiang, T. Han, C. Sun and L. Na, Nutrients, 9(9), 982 (2017)

20. L. Guariguata, D.R. Whiting, I. Hambleton, J. Beagley, U. Linnenkamp and J.E. Shaw, Diabetes Res. Clin. Pract., 103,137(2014), DOI: 10.1016/j.diabres.2013.11.002.

21. F. Nakhoul, Z. Abassi, M. Morgan, S. Sussan and N. Mirsky, J. Am. Soc. Nephrol. , 17, S127 (2006), DOI: 10.1681/ASN.2005121333

22. M. Jamaludin, A.H. N. Nafizah, A.H. Zariyantey and S.B. Budin, Sultan Qaboos Univ Med J., 16, 2, (2016), DOI:10.18295/squmj.2016.16.02.002.

23. IGM. Sanjaya, B.B. Arom and R. Agustini, In Proceedings of LPPM National Conference, Surabaya State University, pp. 899-904 (2018)

24. L. Wen and A. Duffy The Journal of Nutrition, 147(7), 468S (2017), DOI: 10.3945/jn.116.240754

[RJC-5411/2019] 